\title{
The Impact of Non-banking Credit Organization Credits on Economic Growth in Azerbaijan
}

\author{
Alirza Alirzayev ${ }^{1}$, Samira Shamkhalova ${ }^{2}$ \& Aygun Abdulov ${ }^{2}$ \\ ${ }^{1}$ Financial Services Department, "FINCA Azerbaijan” LL NBCO, Azerbaijan \\ ${ }^{2}$ Department of Economics and Management, Azerbaijan State University of Economics (UNEC), Azerbaijan \\ Correspodnence: Alirza Alirzayev, Financial Services Department, "FINCA Azerbaijan” LL NBCO, Azerbaijan.
}

Received: July 9, 2020

doi:10.5430/rwe.v11n5p334
Accepted: September 11, 2020

Online Published: September 13, 2020

URL: https://doi.org/10.5430/rwe.v11n5p334

\begin{abstract}
Financial institutions plays remarkable role in Azerbaijan economy. The general structure of financial institutions in the country includes banks, local branches of foreign banks and non-bank financial institutions, while among these organizations banks have a leading position. Most of the lending activity in Azerbaijan is carried out through banks. This situation shows their special importance in the country's economy. However, NBCOs (Non-Banking Credit Organizations) also have an important position in lending to the individuals in the economy. This article investigates the impact of the NBCOs credits on non-oil GDP in Azerbaijan. For this purpose, the quarterly data covering 2005-2018 were used. For the evaluation, the cointegration methods as CCR (Canonical Cointegrating Regression), DOLS (Dynamic Ordinary Least Squares) and FMOLS (Fully Modified Ordinary Least Squares) methods were employed. The results of cointegration tests conclude that there is cointegration relationship between the variables in long-term. The results of the estimation show that a $1 \%$ rise in credits and physical capital investments increases non-oil GDP by $0.26 \%$ and 0.92 , respectively. Findings of study are in line with both the theory and the results of other researches, and may be considered adequate for Azerbaijan economy. The management and other decision-makers of relevant organizations may adopt effective decisions for more efficient operation of credit organizations by taking into account the results of the research.
\end{abstract}

Keywords: non-banking credit organizations (NBCOs), cointegration, non-oil GDP, capital investments, Azerbaijan economy

\section{Introduction}

Lending is a process of granting temporary funds to borrowers who need money. Its role varies depending on its application. Due to these borrowed funds, production and raising sales could be achieved and eventually growth and development can be increased. There are 2 forms of credits: bank credit and commercial credit. Bank credits are widely used in Azerbaijan and the products essentially offered by banks include consumer, business and mortgage credits. According to the December 2018 report on the banking sector overview, there are 30 banks operating in the country, two of which are state-owned (FIMSA, 2018). In 2018, total loans investments of banks amounted to 1.2628.3 million AZN (CBAR, 2018). In general, the share of banks in total loan investments in 2005-2018 was more than $97 \%$.

Apart from banks, NBCOs also have a certain share in lending to the economy. The activities of the NBCOs, non-bank financial companies, are regulated by the law of Azerbaijan Republic on "Non-banking credit organizations" adopted in 2009. These organizations neither can have the bank license nor can adopt deposits.

According to the report of the Financial Market Supervisory Authority of Azerbaijan Republic (FIMSA) on summary indicators of the bank sector for December of 2018, 104 NBCOs operate in the country and one of them is state-owned (FIMSA, 2018). The other 103 organizations represent the private sector. In addition to this, 57 of the NBCOs are credit unions. The number of NBCOs was 85 in 2005, but afterwards the number of them grew rapidly and reached to 157 in 2015. However after 2015, the number of them began to decline due to the problems occurring in the bank sector in the next period.

In 2005-2018, the average share of the NBCOs in total credits was $2.7 \%$. The highest indicator in percentage was $3.6 \%$ in 2017 which amounted to AZN 420.2 million, and the lowest indicator was $2.1 \%$ that reached AZN 177.0 
million in 2009. In 2018, the share of the NBCOs in total credits was AZN 392.0 million which is equal to 3\% (CBAR, 2018). The highest indicator in amount was 566.0 million AZN in 2015. In that year, the credits were AZN 21730.4 million which was the highest indicator in Azerbaijan. The double devaluation of AZN in the country in 2015 and the subsequent problems in financial system made impact to the credits in the country and consequently, the volume of them was decreased. Since that time, the weight of the non-performing loan has been increased, while the number of the NBCOs has been decreased.

Considering above-mentioned facts, the main goal of this research is to evaluate the impact of activities of the non-banking credit organizations on the economy in Azerbaijan. In order to reach this goal, the link between the activities of the credit organizations in the country and the economic growth will be assessed and relevant recommendations will be made for economy and the financial system. According to our best knowledge, this paper is the first research to investigate the relationship between the non-oil GDP and NBCO credits by using the CCR, DOLS, FMOLS methods for the case of Azerbaijan.

\section{Literature Review}

Nowadays, the impact of credits on economic growth is one of the hot topics. The several theoretical and empirical studies devoted to the analysis of the impact of credits on the economic growth are being investigated nowadays. These related studies are reviewed and it was identified that while some of the studies show a positive relationship between economic growth and credits in some countries, there are several countries where there is even negative or no significant nexus between the indicated variables.

Regarding to the studies which found a positive link between aforementioned economic indicators, Osman (2014) studied the impact of credits on the economic growth in Saudi Arabia, using data covering the period of 1974-2012 by employing the ARDL model. It was identified that there is a cointegration relationship between bank credits and economic growth in long-term. On the other hand, The impact of credits on the economic growth was investigated by Shan and Qi (2006) using the VAR model for China. They found that the financial expansion affects the economic growth. In the case of Azerbaijan, Mukhtarov et al. (2019) examined the effect of the bank loans on the non-oil GDP by employing CCR, DOLS, FMOLS methods to the data spanning from 2005 to 2019 . The results of study revealed that the bank loans and the exchange rate have positive and statistically significant impact on the non-oil GDP in the long-term for Azerbaijan. Another research was dedicated to the impact of credits on the GDP in Brazil's economy. Patricia and Benjamin (2008) conducted VECM model to the monthly data ranging from January 1995 to July 2007. They found that financial development has a significant role in economic growth. Moreover, Tutar and Unluleblebiji (2014) conducted research on the relationship between economic growth and the loans granted to small and medium businesses in Turkey by using monthly data period of December 2006 - June 2011. The Granger causality and Johansen tests were used in the research. The result of the analysis concluded that the loans granted to small and medium business have positive effect on economic growth in Turkey.

However, some studies conclude negative or no significant nexus between credits and economic growth. One example to this could be Leitao's study (2012) on the nexus of economic growth and bank credit in EU - 27. This study indicated that domestic credits have negative relationship with economic growth. But another study done by Cristea (2010) investigated the link between these two variables in Romania. Based on the results, it was obtained that economic growth cannot be raised with the help of private credits, because of no significant relationship.

As can be seen from above-mentioned researches, even if there are some studies which analyze the nexus between credit and economic growth to some extent, there is no study which has been conducted to investigate the relationship between specifically NBCOs credits and non-oil GDP in Azerbaijan. Therefore, the main purpose of this article is to fill in this gap by employing different cointegration methods to observe the long-term effect of NBCOs credits on non-oil GDP. The results of this article will suggest to researchers and policy makers to understand the role of NBCOs credits in economic growth to achieve sustainable development in Azerbaijan and other developing oil-rich countries.

\section{Data}

The data to be used in this research work consists of quarterly data covering 2005-2018. The statistical indicators such as the non-oil GDP covering last 14 years, credits of the NBCOs given to the economy and physical capital investments were used in the research. The graphs of these statistical indicators were provided below.

1. Non-oil GDP - in million AZN, was measured in the form of total value added in the non-oil sector of the country. 


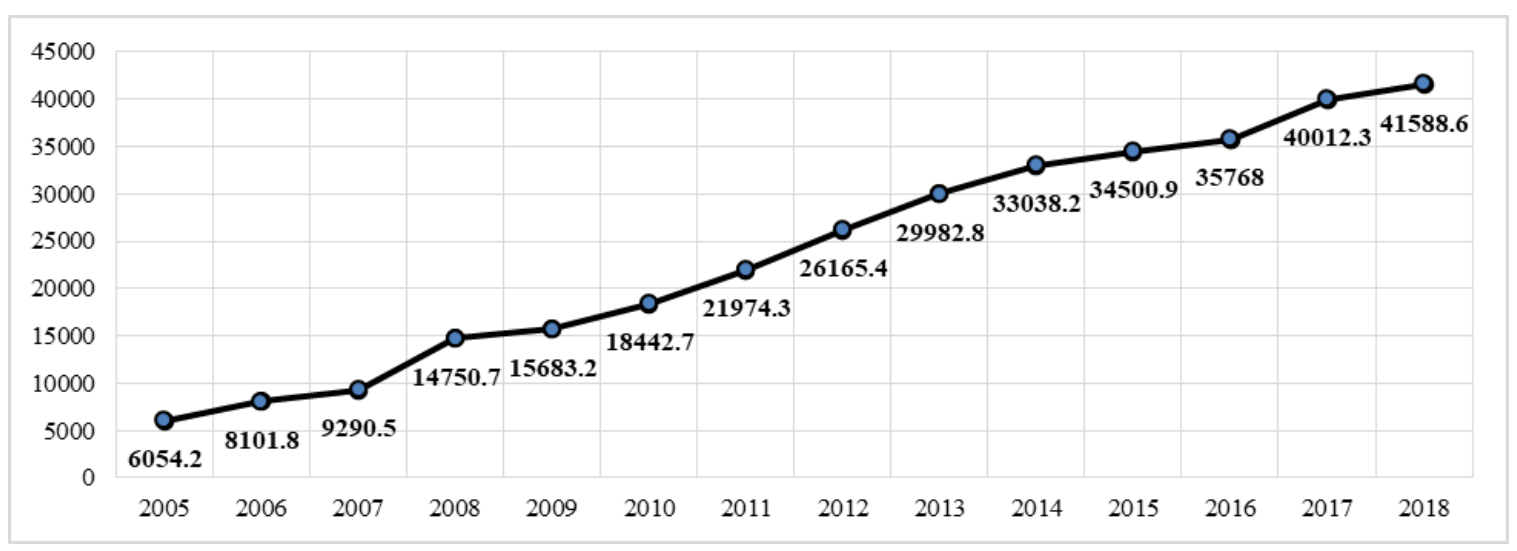

Graph 1. Non-oil GDP, 2005-2018, (in million AZN)

2. Credits - in million AZN, credits granted by non-banking organizations.

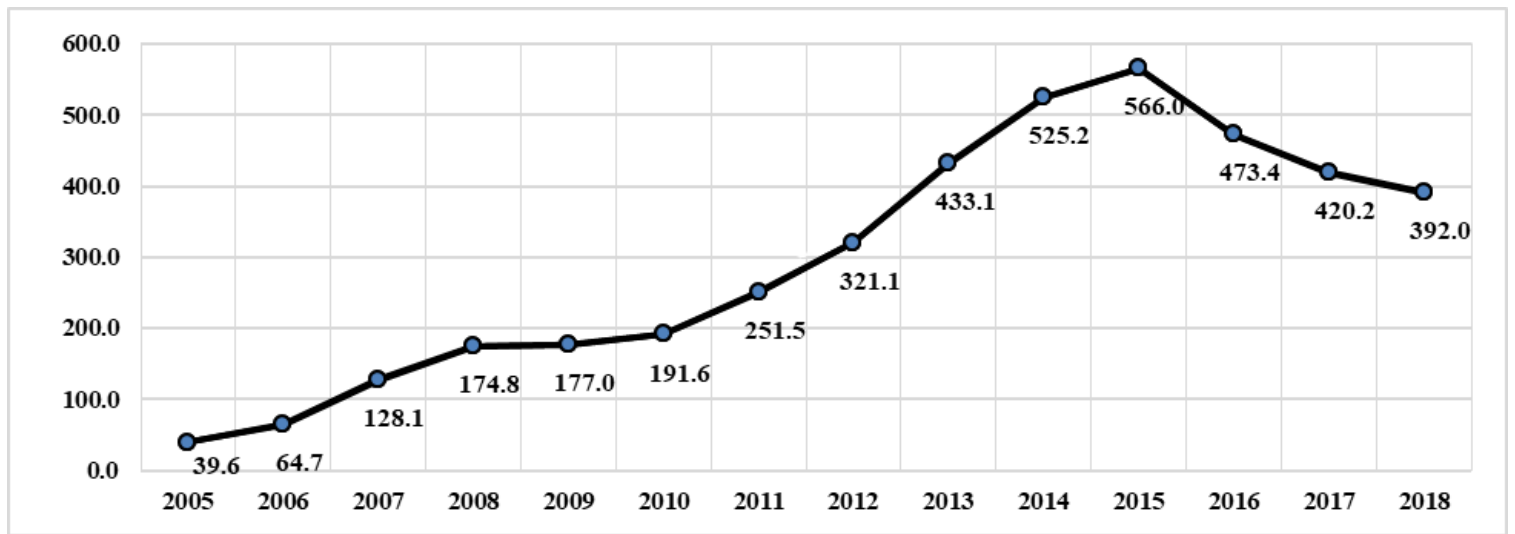

Graph 2. Credits of non-banking credit organizations to the economy, 2005-2018, (in million AZN)

3. Investments (INV) - total physical capital investments in Azerbaijan economy, in million AZN.

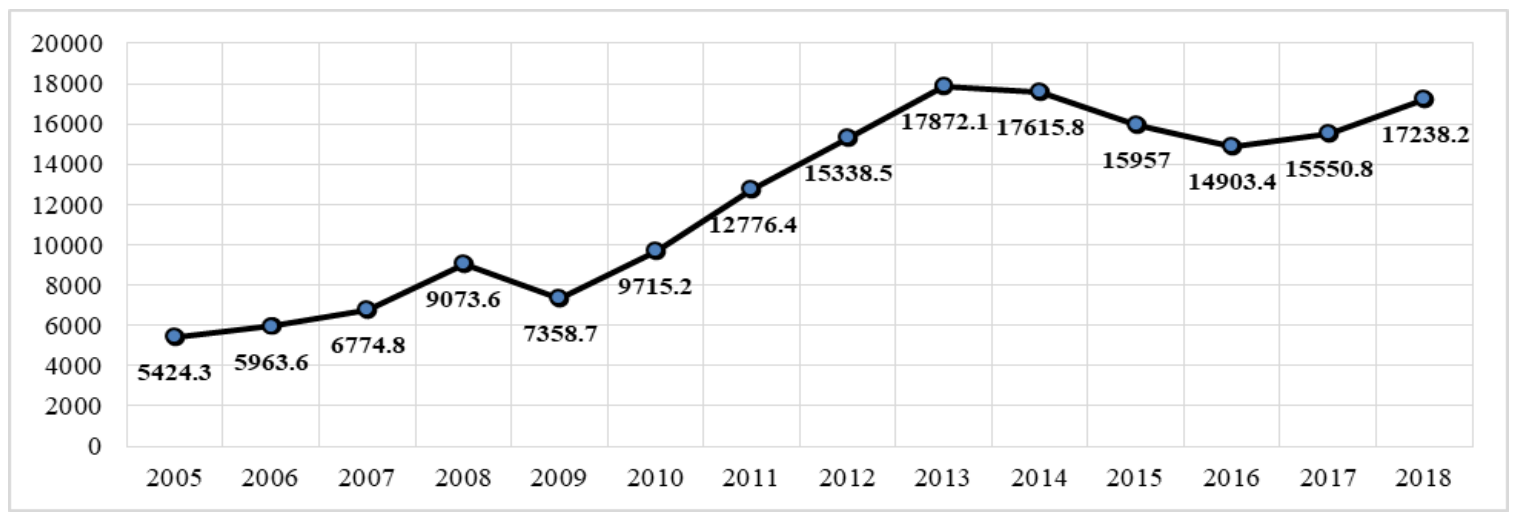

Graph 3. Physical capital investment, 2005-2018 (in mln. AZN)

All statistical indicators above were obtained from the data of the Central Bank of Azerbaijan Republic. 


\section{Methodology}

This article examined the relationship between the non-oil GDP, physical capital investments and the NBCO credits by using different cointegration methods. Central Bank of Azerbaijan (CBAR) was used as the main data sources. NBCO credits were chosen as main predictor variable which could affect non-oil GDP. This choice was backed up with previous papers such as Osman (2014), Patricia and Benjamin (2008), Tutar and Unluleblebiji (2014), Yu (1998), Fedderke et. al. (2006), Tvaronavicius and Tvaronaviciene (2008), and Carlin and Mayer (2003) all of which agreed and obtained that private credits increase economic growth. Also considering well-known Harrod-Domar model or Cobb-Douglas production function which states that physical capital fosters economic growth, the other explanatory variable in the model was chosen to be physical capital investment.

In terms of the steps of empirical analysis, we check stationarity and unit root of variables as the first step. The Augmented Dickey Fuller unit root test (Dickey and Fuller, 1981, ADF) is utilized for this exercise. Then, the Engle-Granger (Engle and Granger, 1987), the Phillips-Ouliaris (Phillips and Ouliaris, 1990) the Park's Added Variables test (Park, 1992) and the Hansen Parameter Instability tests (Hansen, 1992) are employed for testing the cointegration relationship. Next, three time-series methods are used to see the long-run relationship between variables. Firstly, Dynamic Ordinary Least Squares (Stock and Watson, 1993-DOLS) is used as a main tool, then Canonical Cointegrating Regression (Park, 1992- CCR), and Fully Modified Ordinary Least Squares Method (Phillips and Hansen, 1990-FMOLS) methods are employed for the robustness check.

The techniques that were given above are widely used in many previous papers, they are not discussed in this study due to not bother readers with further econometric discussion. However, the detailed information about these methods can be found in Dickey and Fuller (1981), Engle and Granger (1987), Phillips and Hansen (1990), Phillips and Ouliaris (1990), Park (1992) and Stock and Watson (1993), and others.

\section{Estimation Results}

Prior to evaluation of the model, it is important to check the stationarity of the variables. For this purpose, the Augmented Dickey Fuller test was used to check the stationarity of the variables. The results of ADF are presented in the table 1. As seen from the test results, all variables are stationary in the first difference form.

Table 1. Augmented Dickey Fuller single root test results

\begin{tabular}{cccccc}
\hline \multicolumn{7}{c}{ In the level } \\
\hline t-statistics & p-value & Delay level * & \multicolumn{2}{c}{ Test border values ** } \\
\hline GDP & -0.7585 & 0.82 & 4 & $1 \%$ & -3.5654 \\
\hline K & -1.7736 & 0.39 & 2 & $5 \%$ & -2.9199 \\
\hline INV & -1.2015 & 0.67 & 4 & $10 \%$ & -2.5979 \\
\hline \multicolumn{2}{c}{ From the first set difference } & & Test border values ** \\
\hline$\Delta$ GDP & t-statistics & p-value & Delay level * & $1 \%$ & -3.5654 \\
\hline$\Delta \mathrm{K}$ & -3.5220 & 0.01 & 3 & $5 \%$ & -2.9199 \\
\hline$\Delta \mathrm{INV}$ & -2.9356 & 0.04 & 1 & $10 \%$ & -2.5979
\end{tabular}

(*) selected according to Schwarz criteria

(**) p-values for Mackinnon (1996) single sided test

Further, the existence of the cointegration relationship between the variables was tested. For this purpose, the Engle-Granger (Engle and Granger, 1987), the Phillips-Ouliaris (Phillips and Ouliaris, 1990), Park's Added Variables (Park, 1992) and the Hansen Parameter Instability tests (Hansen, 1992) are used and the results are presented in Table 2. According to the results of Engle-Granger and Phillips-Ouliaris approaches, as p-values for the Tau-stat and Z-stat are smaller than 5\% and 10\%. It means, the hypothesis of 'there is no long-term cointegration relationship between variables' is rejected by the 10\% and 5\% level of significance. According to the results of the Hansen parameter instability and the Park's added variable test approach, in all cases p-value was greater than 5\%. In this case, the null hypothesis that "there is cointegration relationship" is not rejected in the 5\% significance level.

Consequently, it means that there is cointegration relationship in the long-term between the variables. 
Table 2. Results of Cointegration Tests

\begin{tabular}{|c|c|c|}
\hline & Engle-Granger & Phillips-Ouliaris \\
\hline \multirow[t]{2}{*}{ Tau-stat } & -3.5987 & -3.7277 \\
\hline & $(0.03)$ & $(0.02)$ \\
\hline \multirow[t]{2}{*}{ Z-stat } & -16.604 & -18.563 \\
\hline & $(0.09)$ & $(0.06)$ \\
\hline Park's Added Variables Test & Hansen Para & bility \\
\hline \multirow[t]{2}{*}{ Chi-square } & $\mathrm{L}_{\mathrm{C}}$ statistics & 0.279791 \\
\hline & $(0.2403)$ & $(0.1873)$ \\
\hline
\end{tabular}

The Table 3 describes the long-term elasticities of variables obtained by using the FMOLS and the CCR cointegration methods along with the DOLS method. As mentioned in the methodology section, detailed interpretation will be made according to the DOLS method due to the fact that it outperforms all the alternative cointegration methods in small samples. In the above-mentioned models, the coefficients of the independent variables are positive and statistically significant as confirmed by the theory. At the same time, the obtained coefficients are closer to each other.

Table 3. Results of the long-term relation evaluation

\begin{tabular}{llll}
\hline Variables & DOLS & FMOLS & CCR \\
\hline $\mathrm{K}$ & $0.26^{* * *}$ & $0.27^{* * *}$ & $0.28^{* * * *}$ \\
\hline INV & $0.92^{* * *}$ & $0.90^{* * *}$ & $0.87^{* * * *}$ \\
\hline $\begin{array}{l}\text { Note: Dependent variable; GDP. }{ }^{* * *}, * * \text { and } * \text { shows that the } 0 \text { hypothesis is rejected in the significance } \\
\text { level of 1\%,5\% and 10\% respectively. Evaluation period: 2005:Q1-2018:Q4 }\end{array}$ \\
\hline
\end{tabular}

The results of the estimation show that, a $1 \%$ in NBCOs credits increases non-oil GDP by $0.26 \%$. Having positive and significant impact of credits, our finding is in line with the results of several studies like, Osman (2014), Shan and Qi (2006), Mukhtarov et al. (2019), Patricia and Benjamin (2008) and Tutar and Unluleblebici (2014). We also find that the non-oil GDP responses by $0.92 \%$ to a $1 \%$ increase in physical capital investments. Our result is consistent with Yu (1998), Fedderke and others (2006), Tvaronavicius and Tvaronaviciene (2008), and Carlin and Mayer (2003). And this coincides with the theory related to the impacts of both credits and physical capital investments on the economic growth and with the results of several other research and may be considered as adequate for Azerbaijan's economy.

\section{Conclusion}

This article has studied the impacts of physical capital investments on non-oil GDP by the credit investments of NBCOs in the economy in Azerbaijan. The evaluation has used the cointegration methods such as the Canonical Cointegration Regression (CCR), the Dynamic Ordinary Least Squares (DOLS) and the Fully Modified Ordinary Least Squares (FMOLS) methods. The estimation results of DOLS show that a $1 \%$ increases in NBCO credits and physical capital investment increase non-oil GDP by $0.26 \%$ and $0.92 \%$, respectively.

The obtained positive effect of credits and physical capital investment indicate that the Azerbaijani financial system should allow firms and household to find easier and less expensive financial fund to establish or develop their businesses and to buy durable goods. If the financial environment is good enough that it permits businesses to get easier financial capital, which can help create a new business or expand existing scale. Hence, proper policies must be introduced and considerable efforts must be made to maintain a well-managed financial system. Without sustainable well-managed financial system, the financial sector may not be able to boost the economic growth. It can be concluded from the result that in order to support the economic growth in Azerbaijan, the NBCOs should take further active part in the economy. Furthermore, new legislations which create positive incentives for NBCOs should 
be promoted. Taking into account the results of the research work, the management and other policy-makers of relevant organizations may adopt effective decisions to achieve more efficient operation of credit organizations.

From other perspective, as Azerbaijan is main oil producing and exporting country, oil revenues take a great share of GDP. But in order to be sustainable in the long run, the country should consider diversification. In this regard, improving finance sector can be one of the ways of diversification. It will also lead to better credit terms and conditions. Consequently, based on our research, better credit conditions will foster economic growth.

The key limitation of this paper is that the data obtainable for Azerbaijan in regards to NBCOs credit, physical capital investment and economic growth nexus are limited and do not cover the period before 2005 .

\section{References}

Ahmad, R. C., \& Andrii, S. (2017). Non-bank financial institutions activity in the context of economic growth: cross-country comparisons. Financial Markets, Institutions and Risks, 1.

Akinchan, B. S. (2017). Non-Banking Financial Institutions of India - Their Onset, Growth and Performance of Selected NBFCs. ICSI-CCGRT \& Research Scholar.

Andy, C. C., Kwan, Wu, Y., \& Zhang, J. (1999). Fixed Investment and Economic Growth in China. Economics of Planning, 32(1), 67-79.

Anupam, D. G., A, Y., \& Md. Omar, F. K. (2013). Growth of Non Bank Financial Institutions Over Time and Contribution to Economy: Evidence from Bangladesh. Global Journal of Management and Business Research Finance, 13.

Carmichael, J., \& Pomcerleano, M. (2002). The development and regulation of non-bank financial institu-tions. Washington, D.C., USA: The World Bank.

Cheng, X., \& Hans, D. (2006). The Impact of Bank and Non-Bank Financial Institutions on Local Economic Growth in China. CentER Discussion Paper, 26.

Cristea, M., \& Dracea, R. (2010). Does credit market accelerate economic growth in Romania? Statistical approaches. Finance - Challenges of the Future Year IX, No. 11/2010, University of Craiova pp. 184-190.

Dickey, D., \& Fuller, W. (1981). Likelihood Ratio Statistics for Autoregressive Time Series with a Unit Root. Econometrica, 49(4), 1057-1072.

Edna, D. C., \& Ndanshau, M. O. A. (2016). The Non-Bank Financial Intermediaries and Economic Growth in Tanzania: An Empirical Analysis 1967-2011. Tanzanian Economic Review, 6.

Engle, R. F., \& Granger, C. W. J. (1987). Co-integration and error correction: representation, estimation and testing. Econometrica, 55(2), 251-276.

Eyas Gaffar Abdelraheem Osman. (2014). The Impact of Private Sector Credit on Saudi Arabia Economic Growth (GDP): An Econometrics Model Using (ARDL) Approach to Cointegration. American International Journal of Social Science, 3(6), 109-117.

Fedderke, J. W., Perkins, P., \& Luiz, J. M. (2006). Infrastructural investment in long-run economic growth: South Africa 1875-2001. World Development, 34(6), 1037-1059.

Filiz, T., \& Ünlüleblebici, Y. (2014). Türkiye`de KOBİ Kreditlerinin Ekonomik Böyümeye Etkisi (2006-2011). Global Journal of Economics and Business Studies, 3(5), 1-14.

Hansen, B. E. (1992). Testing for parameter instability in linear models. Journal of Policy Modeling, 14(4), 517-533.

Jordan, S., \& Qi, J. (2006). Does Financial Development 'Lead' Economic Growth? The Case of China. Annals of Economics and Finance, 1, 197-216.

Law of Azerbaijan "About Bank". (2004).

Law of Azerbaijan "About Non-bank credit organizations". (2009).

Leitao, N. C. (2012). Bank, credit, and economic growth: A dynamic panel analysis. The Economic Research Guardian, 2(2), 256-267.

Mehmet, M. (2013). Kredi Hacmindeki Değişimlerin Ekonomik Büyümeye Etkisi: Türkiye Ekonomisi İçin Sınır Testi Yaklaşımı. Bankacılar Dergisi, 24(84), 54-71.

Michael, B., Tomas, M., \& Andreas, P. (2009). Credit and economic recovery. DNB Working Paper No. 218. 
Monzur, H., \& Md. Shahiduzzaman. (2002). Development of Non Bank Financial Institutions to Strengthen the Financial System of Bangladesh. Journal of Bangladesh Institute of Bank Management, 28.

Mukhtarov, S., Humbatova, S., \& Seyfullayev, İ. (2019). The impact of bank credits on non-oil GDP: evidence from Azerbaijan. Banks and Bank Systems, 14(2), 120-127.

Ndugbu, M. O., Ojiegbe, J. N., Barr. Lawrence, U. N., \& Okere, P. A. (2015). Bank and Non-Bank Financial Institutions and the Development of the Nigerian Economy. International Journal for Innovation Education and Research, 3.

Osuala, A. E., \& Odunze, C. O. (2014). Do Non-Bank Financial Institutions' Loans and Advances Influence Economic Growth? A Bounds Test Investigation. European Journal of Business and Management, 6(27).

Park, J. Y. (1992). Canonical cointegrating regressions. Econometrica, 60(1), 119-143.

Patricia, L. T., \& Benjamin, M. T. (2008). Estimating the credit-gdp elasticity: the case of Brazil. Journal of International Business \& Economics, 8(2), 129.

Phillips, P. C. B., \& Hansen, B. E. (1990). Statistical inference in instrumental variables regression with I(1) processes. Review of Economics Studies, 57(1), 99-125.

Phillips, P. C. B., \& Ouliaris, S. (1990). Asymptotic properties of residual based tests for co-integration. Econometrica, 58(1), 165-193.

Qiao, Y. (1998). Capital investment, international trade and economic growth in China: Evidence in the 1980-90s. China Ecomonic Review, 9(1), 73-84.

Retrieved form https://www.cbar.az/home?language=en

Retrieved form https://www.fimsa.az/en/

Ronald, R., \& Meshach, J. A. (2017). Non-bank financial institutions and economic growth: evidence from selected African countries. South African Journal of Economic and Management Sciences, 20.

Stock, J. H., \& Watson, M. (1993). A simple estimator of cointegrating vectors in higher order integrated systems. Econometrica, 61(4), 783-820.

Vytautas, T., \& Manuela, T. (2008). Role of fixed investments in economic growth of country: Lithuania in European context. Journal of Business Economics and Management, 9(1), 57-64.

Wendy, C., \& Colin, M. (2003). Finance, investment, and growth. Journal of Financial Economics, 69, 191-226.

Zdenko, P., \& Bojana, O. D. (2005) Supervision of Non-Banking Financial Institutions in Croatia. 5th International Conference "Economic Integration, competition and cooperation". Opatija, Croatia.

\section{Copyrights}

Copyright for this article is retained by the author(s), with first publication rights granted to the journal.

This is an open-access article distributed under the terms and conditions of the Creative Commons Attribution license (http://creativecommons.org/licenses/by/4.0/). 